\title{
STUDENTS' PERCEPTION TOWARDS THE USE OF GOOGLE CLASSROOM FOR MATHEMATICS ONLINE LEARNING VIEWED FROM STUDENTS' READINESS
}

\author{
Pradipta Annurwanda $^{1}$, Rahmat Winata ${ }^{2}$ \\ ${ }^{1}$ STKIP Pamane Talino, Ngabang, Landak, Indonesia. \\ pradiptamaospati@gmail.com \\ ${ }^{2}$ STKIP Pamane Talino, Ngabang, Landak, Indonesia \\ gublik.tata@gmail.com
}

\begin{abstract}
Google Classroom is an online learning app that can be used for free and offers many features to support the online learning system and the implementation of Google Classroom must consider the students' readiness in accessing Google Classroom because many students have difficulty in the learning process, which affects the decline in student assignments and exam scores. The purpose of this study was to describe students' perception towards the use of Google Classroom in mathematics learning in terms of students' readiness to take online learning. This study was conducted using a survey on 91 mathematics education students of STKIP Pamane Talino. The instrument used in this study was a questionnaire. The survey results showed that the level of readiness of students was $74.60 \%$ in the very good category. The effectiveness of Google Classroom implementation on online learning was $71.24 \%$ (very good); the use of Google Classroom is effective in learning mathematics in terms of students' readiness for online learning. The results also show that students can access Google Classroom online to ask the tutors, work on assignments and view the answers to their assignments independently and regularly. Students find learning using Google Classroom is effective and fun because students can study material, discuss with teachers, and send assignments remotely.
\end{abstract}

\section{ARTICLE INFORMATION}

\begin{tabular}{|c|c|}
\hline Keywords & Article History \\
\hline $\begin{array}{l}\text { Students' Perception } \\
\text { Students' Readiness } \\
\text { Google Classroom } \\
\text { Online Learning }\end{array}$ & $\begin{array}{l}\text { Submitted Sep 18, } 2021 \\
\text { Revised Nov 8, } 2021 \\
\text { Accepted Nov 11, } 2021\end{array}$ \\
\hline Corresponding Author & \\
\hline $\begin{array}{l}\text { Pradipta Annurwanda } \\
\text { STKIP Pamane Talino } \\
\text { Ngabang, Landak, Indonesia } \\
\text { Email: pradiptamaospati@gmail.com }\end{array}$ & \\
\hline How to Cite & \\
\hline
\end{tabular}

https://doi.org/10.22236/KALAMATIKA.vol6no2.2021pp195-206 


\section{INTRODUCTION}

Online learning systems are implemented through computer devices connected to an internet connection. In Indonesia, the e-learning system is no longer foreign, but not all schools have implemented this system, especially schools located in remote areas or villages (Dwi, Amelia, Hasanah, \& Putra, 2020). Student readiness in following online learning is one of the important processes that must be considered in following the learning.

The observations and interviews with lecturers and students of STKIP mathematics education Pamane Talino show that online learning on campus is already using Google Classroom. Lecturers and students already have devices that can be used for online learning through Google Classroom. However, sometimes the learning process carried out in Google Classroom has problems, such as students being confused about where to find the various features provided by Google Classroom. In addition, students are confused about accessing and submitting assignments, conducting online conferences, displaying a single view, and class integration which affects student learning outcomes.

The progress of mathematics affects the development of science and technology that supports the development of the culture of human life. One of the ability needed by lecturers is designing learning in the classroom so that students get an interesting and enjoyable learning experience. Educators must implement innovative student-centered learning models to improve the quality learning process (Kaplan, Piskin, \& Bol, 2010).

The ability to think critically, logically, and creatively should be expressed in mathematics learning. Solving math problems can help students improve speed, understanding, drafting, breakdown, and logical discovery in mathematics. When students are faced with a situation of math problems in classroom learning, they will try to understand the problem and solve it in ways they know. The combination of ways with technology is one of the efforts to make mathematics learning meaningful. Students are stimulated to participate in the learning process with active collaboration through a co-creation mechanism that encourages student learning progress (Zepke \& Leach, 2010).

The rapid development of technology allows the development of better information services in an educational institution. Therefore, the concept of learning that utilizes information technology will become more effective and efficient through online-based learning (Fujiawati \& Raharja, 2019). The principles of technology utilization that become a 
reference for lecturers in utilizing technology can bring facts into the classroom, provide illustrations of natural phenomena and science, provide students wiggle room to explore and facilitate interaction and collaboration between lecturers and students. Through technology, students can learn anytime, anywhere and can save time, save costs, and easily communicate with teachers through existing technology (Purwandani, 2017). The use of computer technology in mathematics learning provides positive results according to the research results that states the study involving 36,793 students demonstrated a significant positive effect of CT on mathematical achievement statistically in a meta-analysis conducted of 85 independent effect sizes extracted from 46 main studies. (Li \& Ma, 2010).

Some platforms that can be used to do learning that utilizes computer technology are Google Classroom, Edmodo, Moodle, etc. One of the most popular platforms for online learning today is Google Classroom. Google Classroom is an online learning app that you can use for free. Google Classroom is one of the most applicable forms of application in Indonesia because Google Classroom is a structured classroom application in today's learning process (Pradana \& Harimurti, 2017). Google Classroom is available in a mobile app for easy access anytime and anywhere to improve student performance. It integrates with other Google platforms to help educators track student progress and provide instant feedback (Joy et al., 2018). Educators provide opportunities to interact with students asynchronously by providing resources such as content, ideas, and learning assignments that support interactive webs to enhance quality learning processes (Northey, Bucic, Chylinski, \& Govind, 2015). This application offers lecturers to create their classes, share class codes, invite students, share presence, materials, assignments, and evaluations of lectures easily and well administrated. In addition, Google Classroom offers the advantage of setting up a fast and convenient class, saving and time-efficient, improving cooperation and communication, centralized data storage, and sharing resources efficiently, practically, and quickly.

The use of Google Classroom can be accessed via multiplatform, namely through computers and mobile phones. Students can visit https://classroom.google.com site or download it directly through the Play Store on Android or the App Store on IOS. Google Classroom can display text, images, and videos during the learning process and set assignment collection times by educators that will certainly foster discipline for students in doing tasks (Sukmawati, 2020). Using Google Classroom, lecturers can easily add students to classes, 
share assignments, correct and rate easily and save time. Teachers can use Google Classroom to manage classes effectively (Abid Azhar \& Iqbal, 2018). The concept of online learning using Google Classroom can certainly be an interesting study material and provide better results compared to other learning models. To achieve the desired learning objectives, educators need to emphasize and implement technology in the classroom that focuses on student learning abilities through innovative teaching strategies (Hwang, Lai, \& Wang, 2015).

Some research on using Google Classroom suggests that Educators can change classroom learning from teacher-centered to student-centered through open learning activities, inquiry, and creative thinking through Google Classroom (Shaharanee, Jamil, \& Rodzi, 2016). Other results concluded that Google Classroom has an easy design for students because students have used other Google products through their Google Apps accounts (Izenstark \& Leahy, 2015). Then, Google Classroom performance can support learning Education Research Statistics because students are facilitated to store documents such as important materials and assignments sent through Google Classroom (Risnawati, Musa, 2020). Therefore, so far, Google Classroom as an online learning medium has received a positive response from students.

To be able to carry out online learning properly, it is necessary to readiness to learn. Student learning readiness is indispensable in every learning process in the classroom to facilitate students attending lectures and understanding the materials delivered by their lecturers (Hadiningrum, Budaya, \& Soedirman, 2018). Self-readiness is closely related to learning achievements. This finding follows the study results that stated that a very important factor affecting student achievement is learning satisfaction, mastery goals, and readiness for independent learning (Park, Lee, \& Bae, 2010).

Although online learning has become commonplace today, the potential for problems in the implementation of online learning is still quite a lot. Lack of facilities and infrastructure influenced by economic factors and technological unpreparedness is also an obstacle in the progress of online learning activities (Dwi et al., 2020). Potential obstacles in online learning activities include the ability of students to use computers, barriers in accessing the internet, barriers to communicating using the internet, and hardware disruption.

This study aimed to describe the effectiveness of using Google Classroom in math learning reviewed from the readiness of students to participate in online learning. In 
implementing online learning, educators must first measure student readiness before carrying out online learning. Readiness for online learning can be defined as the willingness and ability to organize and participate in learning (Fujiawati \& Raharja, 2019). The willingness of students to receive technology is also a dimension of readiness that needs to be measured. This is very necessary because the level of readiness of students in following online learning is very determining the results of learning that will be achieved. Students welcome the integration of mobile-based learning in education through continuous computing skills (Hussin, Radzi Manap, Amir, \& Krish, 2012). If students have such readiness, online learning can run well and produce outputs according to learning objectives. This encourages the achievement of learning objectives, namely for students to succeed in mastering the material based on the indicators that have been set before (Suprihatiningsih \& Annurwanda, 2019).

\section{METHODS}

The study employed a survey method. A survey was conducted to describe the effectiveness of using Google Classroom in math learning reviewed from the readiness of students to participate in online learning. The variables in this study are: 1) Self-readiness for online learning and 2) Use of Google Classroom.

The subjects in this study were 91 students of mathematics education at STKIP Pamane Talino. The research subject was chosen because the students had used Google Classroom in learning for at least one semester in class. Data collection data in this study involved a questionnaire. The first questionnaire was used to measure the level of readiness of students in following online learning divided into five categories, namely: 1) Self Directed Learning, 2) Learning Preferences, 3) Learning Habits, 4) Technology Skills, and 5) Computer Equipment Capabilities. The self-readiness questionnaire includes 30 online learning items. The second questionnaire was used to measure the effectiveness of using Google Classroom in mathematics learning which is divided into four categories: 1) Ease of access, 2) Usability Level, 3) Communication and interaction, and 4) User Satisfaction. This google classroom effectiveness questionnaire is 23 items.

Quantitative data from questionnaires were analyzed using a measure of central tendency and presented in a table to determine the percentage of questionnaire responses from respondents. The calculation result is compared to the 5-point evaluation format (5EF) specified in Table 1 below (Castle \& Engberg, 2004): 
Table 1. 5-point Evaluation Format

\begin{tabular}{llr}
\hline No & \multicolumn{1}{c}{ Interval } & Category \\
\hline 1 & $0 \%-20 \%$ & Poor \\
2 & $21 \%-40 \%$ & Fair \\
3 & $41 \%-60 \%$ & Good \\
4 & $61 \%-80 \%$ & Very Good \\
5 & $81 \%-100 \%$ & Excellent \\
\hline
\end{tabular}

Based on Table 1, researchers can categorize Google Classroom usage rate in learning based on student answers through the questionnaire that has been provided.

\section{RESULT AND DISCUSSION}

This study was conducted to describe the effectiveness of Google Classroom learning in mathematics learning reviewed from the readiness of students to follow online learning. This study uses questionnaire instruments, namely questionnaires on the level of students' readiness in following online learning and questionnaires on the effectiveness of using Google Classroom given to 91 students of STKIP Pamane Talino. The survey results are explained in the following description.

\section{Students’ Readiness}

For learning readiness, the survey results data was obtained in accordance with Table 2.

Table 2. Cumulative Average of Students' Readiness

\begin{tabular}{llccc}
\hline No & \multicolumn{1}{c}{ Indicators } & Mean & $\begin{array}{c}\text { Average Student } \\
\text { Readiness }\end{array}$ & Category \\
\hline 1 & Self-Directed Learning & 81,93 & & \\
2 & Learning Preferences & 75,71 & & Very Good \\
3 & Learning Habits & 79,52 & & \\
4 & Technology Skills & 72,53 & & \\
5 & Computer Equipment Capabilities & 63,31 & & \\
\hline
\end{tabular}

Based on Table 2, the average student readiness is $74.60 \%$. This means the readiness of STKIP Pamane Talino students falls into the Very Good category. This means that students can learn independently, look for unlimited references given by lecturers only, and operate computers and mobile phones to support the learning process and work on tasks. In Table 2, researchers also looked at the readiness of STKIP Pamane Talino students in the Self-Directed Learning category. The results of the student readiness survey in the category of Self-Directed Learning in accordance with Table 3 follows. 
Table 3. Self-Directed Learning Cumulative Average

\begin{tabular}{llcc}
\hline No & \multicolumn{1}{c}{ Statements } & Mean & $\begin{array}{c}\text { Cumulative } \\
\text { Average }\end{array}$ \\
\hline 1 & I'm good at setting goals and deadlines for myself & 79.12 & \\
2 & I have a strong and good reason to follow online learning & 80.22 & 81.93 \\
3 & I'm used to completing the tasks I started & 81.59 & \\
4 & I didn't stop just because things got tough & 84.07 & \\
5 & I can keep myself on track to follow online learning & 84.62 & \\
\hline
\end{tabular}

Table 3 shows that the cumulative average for the Self-Directed Learning category of STKIP Pamane Talino students is $81.93 \%$. These results show that students have been able to learn on their impulses and organize learning independently for the courses they take and SelfDirected Learning, which stands out also in the category of learning habits. The results of the student readiness survey in the category of learning habits in accordance with Table 4 follows.

Table 4. Learning Habits Cumulative Average

\begin{tabular}{llc} 
No & \multicolumn{1}{c}{ Statements } & $\begin{array}{c}\text { Mean } \\
\text { Cumulative } \\
\text { Average }\end{array}$ \\
\hline $\mathbf{1}$ & I usually study in places where I can read and do tasks without interruption & 85.44 \\
$\mathbf{2}$ & I can ignore the distractions around me when I study & 68.96 \\
$\mathbf{3}$ & I am willing to spend 10-20 hours each week following online learning & 75.00 \\
$\mathbf{4}$ & I keep a record of my assignment, and I know when it's due & 84.07 \\
$\mathbf{5}$ & I plan my work in advance so I can turn in tasks on time & 81.87 \\
$\mathbf{6}$ & When I study, the people around me won't try to bother me & 75.00 \\
$\mathbf{7}$ & I'm willing to use email and other online communication tools to ask classmates & 86.26 \\
\hline
\end{tabular}

Table 4 shows that the cumulative average for the category of learning habits of STKIP Pamane Talino students is $79.52 \%$. These results show that students are used to studying in certain places and planning jobs and can use online communication media to support their learning habits.

\section{The Use Of Google Classroom}

The survey results for the use of Google Classroom are shown in Table 5 below.

Table 5. The Use Of Google Classroom Cumulative Average

\begin{tabular}{llccc}
\hline No & \multicolumn{1}{c}{ Indicators } & Mean & $\begin{array}{c}\text { Google Classroom } \\
\text { Usage Average }\end{array}$ & Category \\
\hline $\mathbf{1}$ & Ease of accessing Google Classroom & 79.05 & & \\
$\mathbf{2}$ & Google Classroom usability level & 64.35 & 71.24 & Very Good \\
$\mathbf{3}$ & Google Classroom communication and interaction & 77.82 & & \\
$\mathbf{4}$ & Google Classroom user satisfaction & 63.74 & & \\
\hline
\end{tabular}

Table 5 shows that the average Google Classroom usage indicator is $71.24 \%$, and this means that the use of Google Classroom by STKIP Pamane Talino students falls into the Very Good category. These results show that Google Classroom provides students with convenience 
because they can interact and communicate anytime and anywhere in online learning to improve the performance of teaching and learning activities, learning motivation, independence, and learning activities.

as seen in Table 5, it stands out in the category of ease of accessing Google Classroom. The survey results are based on Table 6 .

Table 6. Ease of Accessing Google Classroom Cumulative Average

\begin{tabular}{llcc}
\hline No & Statements & Mean & Cumulative Average \\
& & & \\
\hline $\mathbf{1}$ & Using Google Classroom learning media can improve student learning performance & 78.57 & \\
$\mathbf{2}$ & Using Google Classroom learning media can increase students' learning motivation & 77.20 & \\
$\mathbf{3}$ & Using Google Classroom learning media can increase student learning independence & 81.59 & 79,05 \\
$\mathbf{4}$ & Using Google Classroom learning media can improve student learning activities & 78.85 \\
\hline
\end{tabular}

Table 6 shows that the cumulative average for the ease of accessing Google Classroom category of STKIP Pamane Talino students is $79.05 \%$. These results show that students can improve the performance of teaching and learning activities, learning motivation, independence, and learning activities. In addition to the ease of access, there are also prominent categories of Google Classroom communication and interaction. The survey results in that category are in accordance with Table 7 below.

Table 7. Google Classroom Communication and Interaction Cumulative Average

\begin{tabular}{llcc}
\hline No & \multicolumn{1}{c}{ Statements } & $\begin{array}{c}\text { Mean } \\
\text { Cumulative } \\
\text { Average }\end{array}$ \\
\hline 1 & $\begin{array}{l}\text { The use of Google Classroom learning media is an obligation that must be applied in the } \\
\text { classroom during online learning }\end{array}$ & 81.87 \\
2 & $\begin{array}{l}\text { The use of Google Classroom learning media is only part of campus policy and does not } \\
\text { require faculty and students to implement it }\end{array}$ & 67.58 \\
3 & $\begin{array}{l}\text { Using Google Classroom learning media in the classroom is proof that lecturers are keeping } \\
\text { up with the times }\end{array}$ & 83.24 \\
$\begin{array}{l}\text { When learning online, all materials need to be delivered using Google Classroom learning } \\
\text { media }\end{array}$ & 78.57 \\
\hline
\end{tabular}

Table 7 shows that the cumulative average for the Google Classroom communication and interaction category of STKIP Pamane Talino students is $77.82 \%$. These results show that Google Classroom can establish communication and interaction without restrictions on the place and time between lecturers and students.

Based on the analysis for learning readiness and Google Classroom usage, most agree that the effectiveness of using Google Classroom in learning mathematics is reviewed from students' readiness to participate in online learning. This is reinforced by the results of the student learning readiness questionnaire, which is $74.60 \%$ (very good) and the results of the google classroom effectiveness questionnaire, which is $71.24 \%$ (very good). This is in line 
with the study results, which concluded that the effectiveness of using Google Classroom could be seen from the positive response from students (Maharani \& Kartini, 2019; Ermawati et al., 2021).

The questionnaire results show that more than $50 \%$ of students say that learning through Google Classroom has its appeal because it is done online. They also agreed that Google Classroom helps improve problem-solving skills because the teaching materials are fully available in Google Classroom with its features to increase the interest and motivation of students to learn more vigorously. Other research results show that students can follow the lecture well if they are ready to learn something (Hadiningrum et al., 2018).

\section{CONCLUSION}

Based on the results of research and discussion, it can be concluded that the effective use of Google Classroom in mathematics learning is reviewed from the readiness of students to participate in online learning. This finding is reinforced by the results of the student learning readiness questionnaire by $74.60 \%$ with very good categories and the results of the google classroom effectiveness questionnaire by $71.24 \%$ with a very good category. The results also show that students can access Google Classroom online to ask tutors, work on assignments and view the answers to their assignments independently and regularly. Students find learning using Google Classroom is effective and fun because students can study material, discuss with teachers, and send assignments remotely.

\section{ACKNOWLEDGMENTS}

The author expressed his gratitude to STKIP Pamane Talino Landak Regency, who has provided support in the form of facilities and funding subsidies to carry out this research so that research can be carried out smoothly.

\section{REFERENCES}

Abid Azhar, K., \& Iqbal, N. (2018). Effectiveness of Google Classroom: Teachers' Perceptions. Prizren Social Science Journal, 2(2), 52-66.

Castle, N. G., \& Engberg, J. (2004). Response Formats and Satisfaction Surveys for Elders. The Gerontologist, 44(3), 358-367.

Dwi, B., Amelia, A., Hasanah, U., \& Putra, A. M. (2020). Analisis Keefektifan Pembelajaran 
Online di Masa Pandemi Covid-19. Jurnal Pendidikan Guru Sekolah Dasar, 2(1), 3.

Ermawati, E., Sarjana, K., Baidowi, B., \& Sridana, N. (2021). Efektivitas Pembelajaran Daring Matematika Menggunakan Google Classroom Selama Pandemi Covid -19. Griya Journal of Mathematics Education and Application, 1(3), 383-394. https://doi.org/10.29303/griya.v1i3.83

Fujiawati, F. S., \& Raharja, R. M. (2019). Analisis Kesiapan Mahasiswa Pendidikan Seni Mengaplikasikan Pembelajaran Berbasis Online (E-Learning \& Mobile Learning). JPKS (Jurnal Pendidikan Dan Kajian Seni), 4(2), 150-164.

Hadiningrum, I., Budaya, F. I., \& Soedirman, U. J. (2018). Analisis kesiapan belajar mahasiswa dalam mengikuti mata kuliah pragmatics. Prosiding Seminar Nasional Dan Call for Papers " Pengembangan Sumber Daya Perdesaan Dan Kearifan Lokal Berkelanjutan V I I I ”, 14-15(November), 222-229. Retrieved from http://jurnal.lppm.unsoed.ac.id/ojs/index.php/Prosiding/article/view/644

Hussin, S., Radzi Manap, M., Amir, Z., \& Krish, P. (2012). Mobile Learning Readiness among Malaysian Students at Higher Learning Institutes. Asian Social Science, 8(12). https://doi.org/10.5539/ass.v8n12p276

Hwang, G.-J., Lai, C.-L., \& Wang, S.-Y. (2015). Seamless flipped learning: a mobile technology-enhanced flipped classroom with effective learning strategies. Journal of Computers in Education, 2(4), 449-473. https://doi.org/10.1007/s40692-015-0043-0

Izenstark, A., \& Leahy, K. L. (2015). Google classroom for librarians: features and opportunities. Library Hi Tech News, 32(9), 1-3. https://doi.org/10.1108/LHTN-052015-0039

Joy, R., Ventayen, M., Lea, K., Estira, A., De Guzman, M. J., Cabaluna, C. M., \& Espinosa, N. N. (2018). Usability Evaluation of Google Classroom: Basis for the Adaptation of GSuite E-Learning Platform. Asia Pacific Journal of Education, Arts, and Sciences, $5(1), 47-51$.

Kaplan, M. D., Piskin, B., \& Bol, B. (2010). Educational blogging: Integrating technology into marketing experience. Journal of Marketing Education, 32(1), 50-63. https://doi.org/10.1177/0273475309335652 
Li, Q., \& Ma, X. (2010). A meta-analysis of the effects of computer technology on school students' mathematics learning. Educational Psychology Review, 22(3), 215-243. https://doi.org/10.1007/s10648-010-9125-8

Maharani, N., \& Kartini, K. S. (2019). Penggunaan google classroom sebagai pengembangan kelas virtual dalam keterampilan pemecahan masalah topik kinematika pada mahasiswa jurusan sistem komputer. PENDIPA Journal of Science Education, 3(3), 167-173. https://doi.org/10.33369/pendipa.3.3.167-173

Northey, G., Bucic, T., Chylinski, M., \& Govind, R. (2015). Increasing Student Engagement Using Asynchronous Learning. Journal of Marketing Education, 37(3), 171-180. https://doi.org/10.1177/0273475315589814

Park, J. H., Lee, E., \& Bae, S. H. (2010). Factors influencing learning achievement of nursing students in e-learning. Journal of Korean Academy of Nursing, 40(2), 182-190. https://doi.org/10.4040/jkan.2010.40.2.182

Pradana, D. B. P., \& Harimurti, R. (2017). Pengaruh Penerapan Tools Google Classroom pada Model Pembelajaran Project Based Learning terhadap Hasil Belajar Siswa. It-Edu, 2(01).

Purwandani, I. (2017). Analisa Tingkat Kesiapan E-Learning (E-Learning Readiness) Studi Kasus: AMIK Bina Sarana Informatika Jakarta. Bianglala Informatika, 5(2), 102-107. Retrieved

from http://ejournal.bsi.ac.id/ejurnal/index.php/Bianglala/article/view/2976/1895

Risnawati, Musa, T. (2020). Blended Learning Melalui Google Classroom: Studi Kasus di Universitas Islam Negeri Sultan Syarif Kasim Riau. Millennial: Journal for Teachers and Learning, 1(1), 17-24. Retrieved from https://ejournal.anotero.org/index.php/milenial/article/view/17/17

Shaharanee, I. N. M., Jamil, J. M., \& Rodzi, S. S. M. (2016). Google classroom as a tool for active learning. AIP Conference Proceedings, 1761(June 2018). https://doi.org/10.1063/1.4960909

Sukmawati, S. (2020). Implementasi Pemanfaatan Google Classroom Dalam Proses Pembelajaran Online di Era Industri 4 . 0. Jurnal Kreatif Online, 8(1), 39-46. 
Retrieved from http://jurnal.untad.ac.id/jurnal/index.php/JKTO/article/view/15680

Suprihatiningsih, S., \& Annurwanda, P. (2019). Pengembangan Modul Matematika Berbasis Masalah Pada Materi Sistem Persamaan Linear Dua Variabel. Jurnal Karya Pendidikan Matematika, 6(1), 57-63. Retrieved from http://jurnal.unimus.ac.id/index.php/JPMat/index

Zepke, N., \& Leach, L. (2010). Improving student engagement: Ten proposals for action. Active Learning in Higher Education, 11(3), 167-177. https://doi.org/10.1177/1469787410379680 